\title{
A tribute to Dr. Roger Keith (1940-2020)
}

\author{
Allan S. MacDonald, MD \\ Vivian C. McAlister, MB
}

Accepted Jan. 6, 2021

\section{Correspondence to:}

V.C. McAlister

Department of Surgery

London Health Sciences Centre

University Hospital

339 Windermere Rd, Room 4TU44

London ON N6A 5A5

vmcalist@uwo.ca

\section{DOI: $10.1503 /$ cjs.000421}

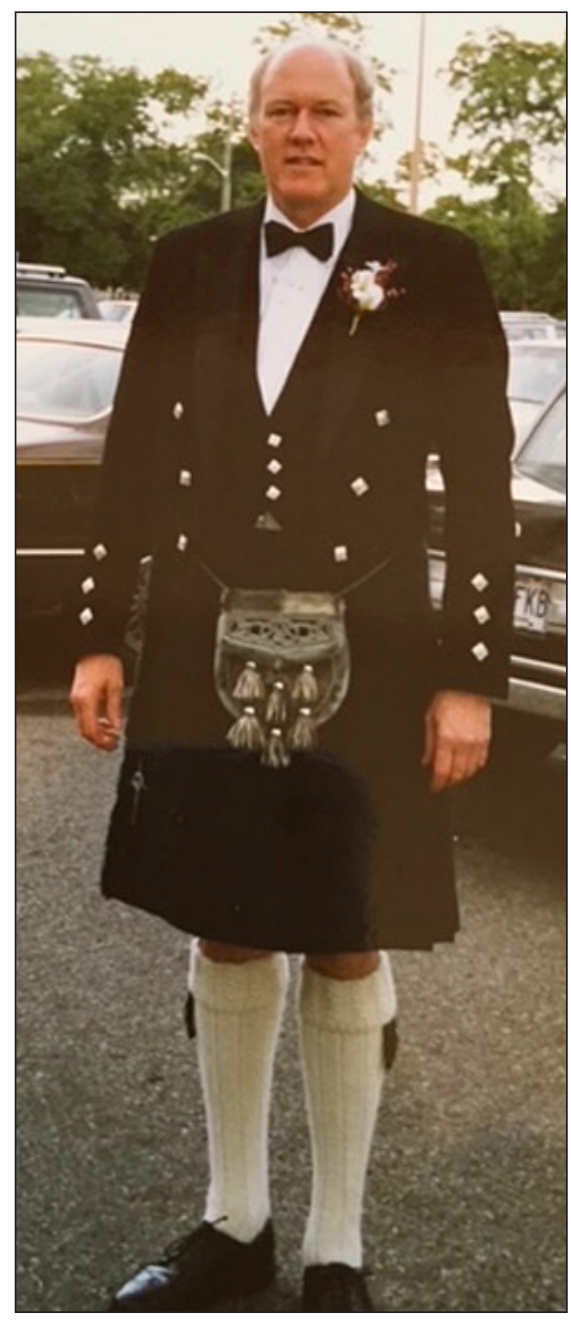

Dr. Roger Keith. Photograph provided by Nancy Keith.

\section{SUMmARY}

Dr. Roger Keith, a former co-editor of the Canadian Fournal of Surgery who died recently in Saskatoon, was a Canadian ambassador for surgery and one of its leaders in North America. His career spans a period when surgery made the greatest progress in its history.

ive years ago, Dr. Roger Keith paid tribute to the late Dr. Lloyd MacLean, who preceded him as co-editor of the Canadian fournal of Surgery (C7S), saying MacLean was a surgeon-scientist and outstanding Canadian ambassador to academic surgery in North America. ${ }^{1}$ The epithet also applies to Roger, ${ }^{2}$ who died recently in Saskatoon in his 80th year.

Born in Calgary, Roger graduated in Medicine from the University of Alberta in 1964. After 2 years of family medicine in Calgary, he entered general surgery residency at the University of Toronto. Thereafter, he completed fellowships in Toulouse, London, Los Angeles and Washington, where his mentors were legends of pancreatic surgery including Jean Lescat, Rodney Smith, William Longmire and Thomas White. He joined the faculty of the Department of Surgery at the University of Toronto in 1973. He established his academic practice at Sunnybrook Medical Centre, and then moved to St. Michael's Hospital as head of general surgery in 1986. Roger became the first Fred Wigmore Professor of Surgery at the University of Saskatchewan, where he was head of surgery from 1990 to 2005 . He was director of clinical affairs at the College of Medicine in Saskatoon and chair of its faculty council from 2014 to 2016. Roger was co-editor of CFS from 1992 to 1996.

Roger was a member of many surgical organizations, always participating on committees and often elected to leadership. He was president of the Canadian Association of General Surgeons (CAGS) and the Central Surgical Society. He served on the executives of the Canadian Association of Gastroenterology, Canadian Association of Clinical Surgeons (Eastern Division), Canadian Association of Surgical Chairs, International Federation of Societies of Endoscopic Surgeons, International Hepato-Pancreato-Biliary Association and the American College of Surgeons. Roger had a career-long interest in the theory of surgical examinations and held leadership roles in the R.S. McLaughlin Examination and Research Centre, the CAGS practice exam, and the Royal College of Physicians and Surgeons of Canada examination board in general surgery. He was elected a director of the James IV Association of Surgeons and a fellow of the American Surgical Association. Roger's inclusion in so many decision-making bodies is best explained by the fact that he was exceptionally perceptive about human behaviour and used wise passion to motivate organizations to do what was right.

Roger adopted the new art of flexible endoscopy in the 1970s and became a leader of endoscopic retrograde cholangiopancreatography. His insistence on the inclusion of endoscopic training in general surgery programs, despite external resistance, was predicated on his belief that it made the graduates better surgeons and improved their treatment of patients with gastrointestinal problems. He developed an expertise in the critical care of patients with septic shock, until then considered unsalvageable. He introduced and developed surgical care of hepatobiliary and pancreatic malignancies. With his good friend Dr. Andrew 
Warshaw, Roger developed minor duct sphincteroplasty for pancreas divisum - a procedure they both later characterized as tilting at windmills. In his 1998 presidential address to CAGS, Roger surveyed, from a first-hand perspective, the development of Canadian surgery from the inception of the society in $1977 .^{3}$ He advocated for inclusion of community surgery in the society. He was instrumental in ensuring survival of CFS when the Royal College removed its financial support by committing CAGS to sponsorship of the journal, which endures to this day.

Keith-trained surgeons work in academic and community practices all across North America today. Participation in so many societies necessitated constant travel, which was interrupted only by the coronavirus disease 2019 pandemic. A highlight, for the authors of this tribute, at some of these conventions, was seeing Roger with his wife Nancy, meetings that always felt like the reunion of family.
Affiliations: From Cape Breton Regional Hospital, Sydney, NS (MacDonald); and the University Hospital, London, Ont. (McAlister).

Competing interests: None declared.

Content licence: This is an Open Access article distributed in accordance with the terms of the Creative Commons Attribution (CC BYNC-ND 4.0) licence, which permits use, distribution and reproduction in any medium, provided that the original publication is properly cited, the use is noncommercial (i.e., research or educational use), and no modifications or adaptations are made. See: https://creativecommons. org/licenses/by-nc-nd/4.0/

\section{References}

1. Keith RG. A tribute to Lloyd D. MacLean. Can 7 Surg 2015;58:2234.

2. McAlister V. Festschrift in honour of Dr. Roger Keith. Can 7 Surg 2016;60:6-7.

3. Keith RG. Canadian Association of General Surgeons presidential address 1988. Advocacy - answering old mail. Can 7 Surg 1999;42:177-80. 